\title{
Genome-wide analysis of the role of GlnR in Streptomyces venezuelae provides new insights into global nitrogen regulation in actinomycetes
}

\author{
Steven T Pullan², Govind Chandra', Mervyn J Bibb ${ }^{1}$ and Mike Merrick ${ }^{1 *}$
}

\begin{abstract}
Background: $G \ln R$ is an atypical response regulator found in actinomycetes that modulates the transcription of genes in response to changes in nitrogen availability. We applied a global in vivo approach to identify the GInR regulon of Streptomyces venezuelae, which, unlike many actinomycetes, grows in a diffuse manner that is suitable for physiological studies. Conditions were defined that facilitated analysis of GlnR-dependent induction of gene expression in response to rapid nitrogen starvation. Microarray analysis identified global transcriptional differences between $g \ln R^{+}$and $g \ln R$ mutant strains under varying nitrogen conditions. To differentiate between direct and indirect regulatory effects of GlnR, chromatin immuno-precipitation (ChIP) using antibodies specific to a FLAGtagged GlnR protein, coupled with microarray analysis (ChIP-chip), was used to identify GlnR binding sites throughout the $S$. venezuelae genome.

Results: GlnR bound to its target sites in both transcriptionally active and apparently inactive forms. Thirty-six GlnR binding sites were identified by ChIP-chip analysis allowing derivation of a consensus GlnR-binding site for S. venezuelae. GInR-binding regions were associated with genes involved in primary nitrogen metabolism, secondary metabolism, the synthesis of catabolic enzymes and a number of transport-related functions.

Conclusions: The GlnR regulon of $S$. venezuelae is extensive and impacts on many facets of the organism's biology. GlnR can apparently bind to its target sites in both transcriptionally active and inactive forms.
\end{abstract}

\section{Background}

The effective assimilation and utilisation of nitrogen are challenges shared by all bacterial species. The mechanisms of regulation of nitrogen metabolism vary greatly but in most organisms overall control is mediated by a global transcriptional regulator [1-3]. GlnR is one such transcriptional regulator belonging to the OmpR winged helix-turn-helix family. It plays a key regulatory role in the expression of genes involved in nitrogen metabolism in several actinomycetes, including Streptomyces coelicolor [4], Amycolatopsis mediterranei [5], Mycobacterium smegmatis [6] and the human pathogen Mycobacterium tuberculosis [7].

GlnR was first identified in S. coelicolor by its ability to restore wild-type growth to a glutamine auxotroph

\footnotetext{
* Correspondence: mike.merrick@bbsrc.ac.uk

'Department of Molecular Microbiology, John Innes Centre, Norwich Research Park, Norwich, Norfolk NR4 7UH, UK Full list of author information is available at the end of the article
}

[8]. It was subsequently shown to activate expression of genes involved in ammonium assimilation, including $g \ln A$ and $g \ln I I$ that encode glutamine synthetase isoenzymes GSI and GSII, respectively, and $a m t B$ that encodes an ammonium transporter [9]. Co-transcribed with $a m t B$ are $g \ln K$ and $g \ln D$, which encode an unusually modified (adenylylated) PII protein and its partner adenylyltransferase, respectively [10]. A second OmpRlike regulator, highly similar to GlnR, is encoded by $g \ln R I I$, which lies adjacent to $g \ln I I$. GlnRII binds to the same promoter sequences as GlnR, but its role in nitrogen metabolism is not known [9].

The range of genes regulated by GlnR in S. coelicolor was extended by the work of Tiffert et al. [11] initially using a bioinformatic approach. By searching for promoters containing a consensus GlnR-binding sequence and verifying GlnR binding activity in vitro, they identified 10 new GlnR targets. These included genes involved in the utilisation and assimilation of various nitrogen
C Biomed Central 
sources, such as nitrite and urea, as well as multiple genes with uncharacterised functions. Recently $S$. coelicolor nas $A$, encoding nitrate reductase, was also found to be regulated by $G \ln R$ through an interaction with a promoter sequence somewhat different from those previously association with GlnR binding [12]. Thus while a predictive bioinformatic approach can be extremely powerful, and has indeed provided considerable insight into the GlnR regulon of $S$. coelicolor, it is by no means comprehensive. The existence of unusual GlnR binding sequences, such as that found upstream of nas $A$, implies that there may be other, as yet undiscovered, GlnR target genes. The recent demonstration that the expression of $g \ln R$ and of some of the GlnR-regulated genes of $S$. coelicolor is subject to repression by $\mathrm{PhoB}$, the response regulator component of the phosphate sensing system [13], highlights the cross-talk that can occur between regulatory systems involved in the global coordination of primary metabolism. Thus, the regulatory effects of GlnR may extend beyond primary nitrogen metabolism, and indeed a recent proteomic analysis of the GlnR-mediated response to nitrogen limitation in S. coelicolor also came to this conclusion [14]. Interestingly, the GlnR orthologue of $A$. mediterranei is involved in the regulation of rifamycin production and its heterologous expression in S. coelicolor had marked effects on secondary metabolism, causing precocious production of undecylprodigiosin and inhibiting actinorhodin production [15]. Such observations suggest that GlnR may play a role in the regulation of secondary metabolism in other actinomycetes. Intriguingly, in Streptomyces venezuelae chloramphenicol production is influenced by the availability of both nitrogen and carbon [16].

The aim of this study was to apply a global in vivo approach to the identification of GlnR and GlnRIIregulated genes. Global transcriptional profiles of $g \ln R$ and $g \ln R I I$ mutants were compared to that of the wildtype strain during growth in varying conditions of nitrogen availability to identify changes in gene expression dependent on either regulator. In addition, global analysis of GlnR-DNA interactions was performed using chromatin immunoprecipitation coupled to microarray analysis of enriched target sites (ChIP-chip).

S. venezuelae was chosen for this study for several reasons. It grows in a diffuse and homogenous manner in a variety of liquid media, and in some sporulates to near completion [17]. Such growth characteristics reduce the physiological heterogeneity inevitably associated with the irregularly sized mycelial clumps observed in most actinomycete liquid cultures. This, together with the availability of S. venezuelae microarrays suitable for both transcriptional and ChIP-chip analyses, made this organism an extremely attractive system for such physiological studies.

\section{Results}

\section{GInR and GInRII in S. venezuelae}

The S. venezuelae genome sequence [GenBank Accession No. FR845719] encodes predicted homologues of GlnR and GlnRII, both of which occur in regions with a high degree of synteny with the respective chromosomal locations in S. coelicolor. S. venezuelae GlnR and GlnRII show $80.6 \%$ and $67 \%$ identity, respectively, to their S. coelicolor homologues.

\section{Defining conditions for induction of the GlnR regulon}

To aid in the accurate interpretation of global transcriptional data, a minimal Evans medium [18] was used that precisely defined the sources of all nutrients, providing a clear physiological perspective for data analysis. S. venezuelae showed reproducible, vigorous growth in Evans medium containing $30 \mathrm{mM}$ ammonium chloride as nitrogen source. A maximum growth rate of $0.27 \mathrm{~h}^{-1}$ was achieved during exponential phase and consistently dispersed mycelium throughout growth was verified microscopically (data not shown).

To determine conditions suitable for global transcriptional analysis, qRT-PCR was used to examine the effect of various growth conditions on transcription of the well-characterised GlnR target $a m t B$ [9]. Optimal induction of $a m t B$ occurred in response to a switch from mid-log growth in Evans containing $30 \mathrm{mM}$ ammonium chloride to Evans medium completely lacking a nitrogen source for a $30 \mathrm{~min}$ period. This induction was almost entirely reversed by the exogenous addition of $30 \mathrm{mM}$ ammonium chloride to the starved culture for a $15 \mathrm{~min}$ period. Transcript levels of $a m t B$, assessed by quantitative reverse-transcriptase polymerase chain reaction (qRT-PCR), were induced 53 -fold by nitrogen starvation and this level was reduced 9 -fold by ammonium addition (Figure 1).

\section{Global transcriptional changes in response to nitrogen status}

RNA samples harvested from three time points $\left(\mathrm{T}_{0}\right.$ prior to $\mathrm{N}$ starvation, $\mathrm{T}_{30}-30$ mins after $\mathrm{N}$ starvation, and $\mathrm{T}_{45}-15$ mins after addition of ammonium) were used to produce cDNA for hybridisation to Affymetrix GeneChips. Three separate biological replicates of this experiment provided a global transcriptional profile of gene expression under conditions that had a marked effect on $a m t B$ expression. The microarray data confirmed the pattern of $a m t B$ expression measured using qRT-PCR, i.e. the gene was strongly induced (76-fold) upon $\mathrm{N}$ starvation and was repressed (15-fold) by exogenous addition of ammonium (Additional file 1). To identify genes with a similar pattern of gene expression, data were filtered to include those genes that were both 


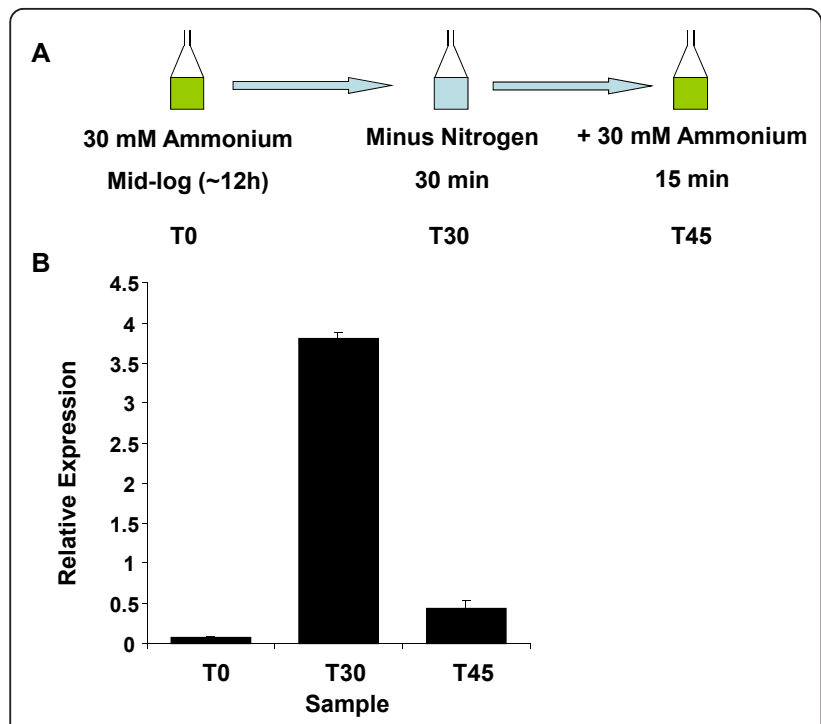

Figure 1 amt $B$ is induced during nitrogen starvation, and repressed by the presence of ammonium chloride. (A) Time course and conditions used in the majority of experiments in this study. (B) qRT-PCR measurement of amtB transcript levels over the time course. Expression levels under each condition were normalised to levels of the mRNA of the major vegetative sigma factor gene, hrdB. Data was collected from three independent biological samples with triplicate technical repeats of each QPCR reaction. Error bars represent standard deviation.

induced $>2$ fold in response to $\mathrm{N}$-limitation and repressed by $>2$ fold in response to the exogenous addition of ammonium. In total 116 genes (Additional file 2) fitted these criteria. A truncated list of the twenty genes showing the largest degree of induction upon $\mathrm{N}$ starvation is given in Table 1 . The fact that the majority of inductions observed are not equally matched by the repression following the re-addition of ammonium may be due to the persistence of mRNA after transcriptional activation has been abolished. The majority of genes that are highly induced are so because the level of expression prior to induction is very low. Therefore a relatively low number of persisting transcripts can have a large effect on the change in expression level when viewed in terms of a fold change.

This list includes a number of genes, e.g. $a m t B$ and glnII, previously demonstrated to respond to changes in nitrogen status in a GlnR-dependent manner in S. coelicolor [11]. Other genes that showed a similarly dramatic response upon microarray analysis, such as Sven_2720 encoding a putative transcriptional regulator fused to a uroporphyrinogen III synthase-like domain (homologous to SCO2958), were therefore also strong candidates for GlnR regulation. However, the stringent N-limitation conditions used in these experiments could also have induced expression of genes responding to reduced growth rate or of those involved in general starvation responses. Indeed this might be indicated by the induction of several uncharacterised transport systems (Table 1). To identify responses that were GlnRmediated, a comparative transcriptional approach was taken using $g \ln R$ and $g \ln R I I$ mutant strains.

\section{Construction and analysis of mutant strains}

To identify which of the transcriptional changes occurring over the time-course were GlnR- or GlnRII-dependent, experiments were performed with mutant strains lacking each of the regulatory proteins. Mutants were generated using PCR-targeting [19], which replaced the entire coding region of each gene with an apramycin resistance cassette. Phenotypic analysis of growth on solid Evans media with ammonium, glutamine, glutamate, nitrate, asparagine or casamino acids as nitrogen source revealed no gross phenotypic differences between the wild-type and $g \ln R I I$ mutant strain M1245 on any nitrogen source tested. The $g l n R$ mutant strain M1246 showed a slight reduction in growth rate on each nitrogen source, but the only one on which it failed to grow entirely was nitrate, consistent with previous observations in S. coelicolor [11].

\section{Effects of $g \ln R$ or $g \ln R / I$ mutation on global transcription}

Of the 116 genes in the wild-type strain that showed a significant induction during $\mathrm{N}$-starvation, and repression upon the addition of exogenous ammonium chloride (Additional file 2), 70 failed to respond to identical conditions in the $g \ln R$ mutant (Additional file 3). GlnRdependent genes induced $>5$ fold by $\mathrm{N}$-starvation in the wild-type strain but not in the $g \ln R$ mutant are listed in Table 2 .

In contrast to the major transcriptional changes observed in the $g \ln R$ mutant, deletion of $g \ln R I I$ did not significantly perturb the expression of any genes noted previously to respond to changes in nitrogen availability (Table 1). 165 genes showed a significant change in expression upon nitrogen starvation when the $g \ln R I I$ mutant was compared to the wild-type strain. However most of these genes exhibited considerably smaller fold changes than those caused by $g \ln R$ mutation. Only 7 genes showed a difference of greater than 5-fold, with the highest being a 13-fold increase in expression of Sven_1878 encoding a putative integral membrane protein of unknown function. None of these genes were homologous to genes implicated in nitrogen metabolism in other systems. In an attempt to determine a physiological role for GlnRII, we used the motif-finding program MEME [20] (http://meme.sdsc.edu) to search for a sequence motif within the upstream regions of genes whose transcriptional profile was altered in the $g \ln R I I$ mutant. No common feature was detected. 
Table 1 The 20 genes showing the greatest fold induction upon nitrogen starvation, that are also repressed by ammonium

\begin{tabular}{|c|c|c|c|c|}
\hline Gene ID & S. coelicolor homologue & Annotation & Fold Induction in WT at T30 & Fold Repression in Wt at T45 \\
\hline Sven_5279 & SCO5583 & $\begin{array}{l}\text { ammonium } \\
\text { transporter } a m t B\end{array}$ & 76.4 & 15.0 \\
\hline Sven_5281 & SCO5585 & $\begin{array}{c}\text { PII } \\
\text { uridylyltransferase } \\
g \ln D\end{array}$ & 26.0 & 8.3 \\
\hline Sven_2720 & SCO2958 & $\begin{array}{l}\text { putative } \\
\text { transcriptional } \\
\text { regulator }\end{array}$ & 21.6 & 6.0 \\
\hline Sven_5280 & SCO5584 & $\begin{array}{c}\text { nitrogen } \\
\text { regulatory protein } \\
\text { PII glnK }\end{array}$ & 16.0 & 6.8 \\
\hline Sven_2606 & SCO2816 & $\begin{array}{l}\text { conserved } \\
\text { hypothetical } \\
\text { protein }\end{array}$ & 15.4 & 3.9 \\
\hline Sven_0745 & SCO1118 & $\begin{array}{l}\text { putative integral } \\
\text { membrane } \\
\text { protein }\end{array}$ & 13.6 & 9.9 \\
\hline Sven_4809 & SCO5163 & unknown & 12.5 & 3.7 \\
\hline Sven_0933 & - & $\begin{array}{l}\text { putative } \\
\text { cholesterol } \\
\text { esterase }\end{array}$ & 11.7 & 7.2 \\
\hline Sven_6300 & SCO6803 & $\begin{array}{c}\text { putative } \\
\text { acetyltransferase }\end{array}$ & 9.8 & 2.9 \\
\hline Sven_4564 & SCO4896 & $\begin{array}{c}\text { putative transport } \\
\text { integral } \\
\text { membrane } \\
\text { protein }\end{array}$ & 9.2 & 7.3 \\
\hline Sven_1595 & SCO1963 & $\begin{array}{l}\text { putative integral } \\
\text { membrane export } \\
\text { protein }\end{array}$ & 8.7 & 2.2 \\
\hline Sven_3456 & SCO6809 & $\begin{array}{l}\text { putative integral } \\
\text { membrane } \\
\text { transport protein }\end{array}$ & 7.9 & 6.2 \\
\hline Sven_1523 & - & unknown & 7.7 & 4.5 \\
\hline Sven_2474 & SCO5348 & $\begin{array}{l}\text { putative } \\
\text { excisionase }\end{array}$ & 7.4 & 2.7 \\
\hline Sven_3334 & SCO3564 & $\begin{array}{c}\text { putative } \mathrm{Na}^{+} / \mathrm{H}^{+} \\
\text {antiporter }\end{array}$ & 7.3 & 4.6 \\
\hline Sven_0739 & SCO1109 & $\begin{array}{c}\text { putative } \\
\text { oxidoreductase }\end{array}$ & 7.2 & 4.4 \\
\hline Sven_3030 & SCO3185 & $\begin{array}{c}\text { putative } \mathrm{Na}^{+} / \mathrm{H}^{+} \\
\text {antiporter }\end{array}$ & 7.1 & 4.1 \\
\hline Sven_0867 & SCO1293 & $\begin{array}{c}\text { putative } \\
\text { acetyltransferase }\end{array}$ & 6.7 & 5.2 \\
\hline Sven_1874 & SCO2210 & $\begin{array}{l}\text { glutamine } \\
\text { synthetase II g/nll }\end{array}$ & 6.5 & 3.6 \\
\hline Sven_3001 & SCO3167 & $\begin{array}{l}\text { putative TetR- } \\
\text { family } \\
\text { transcriptional } \\
\text { regulator }\end{array}$ & 6.4 & 7.5 \\
\hline
\end{tabular}

Full list of genes induced $>2$ are shown in Additional file 2. Fold induction is calculated as the ratio signal T30/signal T0. Fold repression is the ratio signal T30/signal T45. Values given are the average of three hybridisations using cDNA generated from three independent biological experiments. Annotations taken from StrepDB database (http://strepdb.streptomyces.org.uk).

\section{Direct or indirect regulation by $\mathrm{GlnR}$}

While the 70 genes in Additional file 3 exhibited a marked GlnR-dependent change in transcription in response to altered nitrogen status, these genes could be directly regulated by GlnR or could be regulated by factors downstream of GlnR in a possible regulatory cascade. Such indirect regulation was also recently proposed by Tiffert et al. [14]. Of the 70 genes, eight encode 
Table 2 Genes induced $>5$ fold by nitrogen starvation and repressed by ammonium in the wild-type strain, but non-responsive in the $g / n R$ mutant strain

\begin{tabular}{|c|c|c|}
\hline Gene ID & $\begin{array}{l}\text { S. coelicolor } \\
\text { homologue }\end{array}$ & Annotation \\
\hline Sven_5279 & SCO5583 & ammonium transporter, $a m t B$ \\
\hline Sven_5281 & SCO5585 & PII uridylyltransferase, $g \ln D$ \\
\hline Sven_2720 & SCO2958 & putative transcriptional regulator \\
\hline Sven_2606 & SCO2816 & conserved hypothetical protein \\
\hline Sven_6300 & SCO6803 & putative acetyltransferase \\
\hline Sven_4564 & SCO4896 & putative integral membrane protein \\
\hline Sven_1595 & SCO1963 & $\begin{array}{c}\text { putative integral membrane export } \\
\text { protein }\end{array}$ \\
\hline Sven_2474 & SCO5348 & putative excisionase \\
\hline Sven_3334 & SCO3564 & putative $\mathrm{Na}^{+} / \mathrm{H}^{+}$antiporter \\
\hline Sven_0867 & SCO1293 & $\begin{array}{l}\text { c-terminal homology to } \\
\text { acetyltransferase }\end{array}$ \\
\hline Sven_1874 & SCO2210 & glutamine synthetase II gln / \\
\hline Sven_5427 & SCO5772 & putative cysteine dioxygenase \\
\hline Sven_1172 & SCO1578 & acetylglutamate kinase \\
\hline Sven_3383 & - & $\begin{array}{c}\text { putative PIN domain containing } \\
\text { protein }\end{array}$ \\
\hline Sven_0779 & - & putative permease \\
\hline Sven_6135 & - & $\begin{array}{c}\text { putative major facilitator super family } \\
\text { transporter }\end{array}$ \\
\hline Sven_2419 & SCO2636 & unknown \\
\hline Sven_1169 & SCO1572 & putative secreted protein \\
\hline Sven_4152 & SCO4337 & $\begin{array}{c}\text { putative integral membrane efflux } \\
\text { protein }\end{array}$ \\
\hline Sven_1173 & SCO1579 & putative glutamate $\mathrm{N}$-acetyltransferase \\
\hline Sven_2176 & SCO2362 & unknown \\
\hline
\end{tabular}

A full list of genes induced $>2$ fold is shown in Additional file 3 .

putative transcriptional regulatory proteins and another encodes an RNA polymerase sigma factor, and changes in the levels of these proteins would likely affect the expression of their target genes. Equally, any changes in the levels of metabolites that occur during growth in the absence of GlnR could post-translationally affect the activities of other transcriptional regulators and thereby also alter the transcriptional profile. This is a fundamental limitation of transcriptional profiling. Hence, to identify genes directly regulated by $G \ln R$, i.e. by interaction of the protein with their promoter regions, a ChIP-chip approach was taken.

\section{GInR ChIP-chip}

For ChIP experiments, a construct was made in which GlnR carried a C-terminal 3xFlag-epitope tag. The construct (pIJ12248) allows the expression of GlnRFlag under the control of the native $g \ln R$ promoter from a plasmid integrated at the phage $\phi \mathrm{BT} 1$ attachment site [21]. The construct was transferred into the $g \ln R$ mutant M1246 by conjugation to create M1255. Detection of GlnR-Flag at all three stages of the time course experiment was confirmed by Western blotting (Figure 2A), and functionality of the fusion protein was confirmed by the restoration of growth of M1256 on nitrate as sole nitrogen source (data not shown).

Immunoprecipitation (IP) trials, followed by Western blotting, demonstrated enrichment of GlnR-Flag protein following IP (Figure 2B). DNA eluted from the precipitated protein complexes was confirmed by PCR to include the promoter region of $g \ln I I$, a defined GlnR target, but not that of $h r d B$ which encodes the major sigma factor of $S$. venezuelae and which did not respond to changes in nitrogen status in the microarray experiments (Figure $2 \mathrm{C})$. Having confirmed enrichment of GlnR target sequences, IP DNA was labelled with Cy-3 and hybridised to fully-tiled whole genome arrays of S. venezuelae (Oxford Gene Technology). Samples were taken at each of the three time points used for transcriptional analysis, and hybridised along with Cy-5-labelled control samples of total DNA from the same time point that had not been subjected to immunoprecipitation.

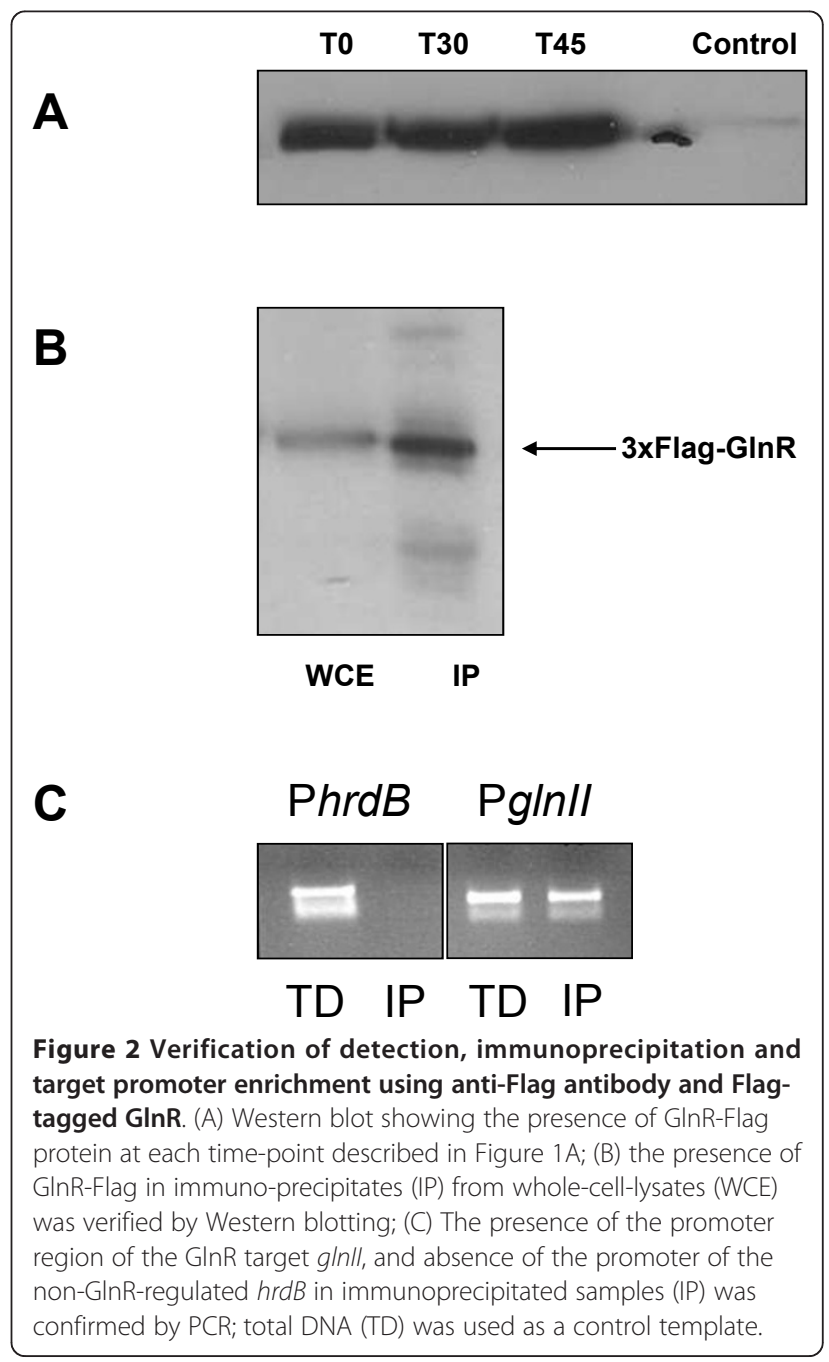


Plotting the Cy3/Cy5 ratio across the chromosome allowed identification of peaks corresponding to GlnRassociated sites. Peaks were considered significant when at least 2 consecutive probes had a $\mathrm{Cy} 3 / \mathrm{Cy} 5$ ratio greater than 2.5 standard deviations above the mean of all signals. This analysis was carried out in duplicate on separate biological samples. As a further control, immunoprecipitation was carried out using the wild-type strain carrying the empty Flag vector (pIJ10500) and therefore not making the GlnR-Flag fusion protein. Peaks that were also present in this sample were considered to be artefacts. Figure 3 shows an example of a GlnR-dependent binding site located within the $g \ln I I$ promoter region.

GlnR binding is promoted by nitrogen starvation, but is not abolished by ammonium addition

At time point $T_{0}$ (Figure 1a), representative of mid-log phase in the presence of $30 \mathrm{mM}$ ammonium chloride, a single significant GlnR-dependent peak was identified that corresponded to the promoter region of $g \ln A$ (Figure 4). This low level of binding at target promoters is consistent with the transcriptional data from both microarrays and qRT-PCR analysis that shows low transcriptional activity from GlnR-target promoters under conditions of nitrogen sufficiency. Binding to the $g \ln A$ promoter at this time is also consistent with relatively higher levels of $g \ln A$ transcription at $\mathrm{T}_{0}$ and lower levels of induction upon nitrogen starvation when compared

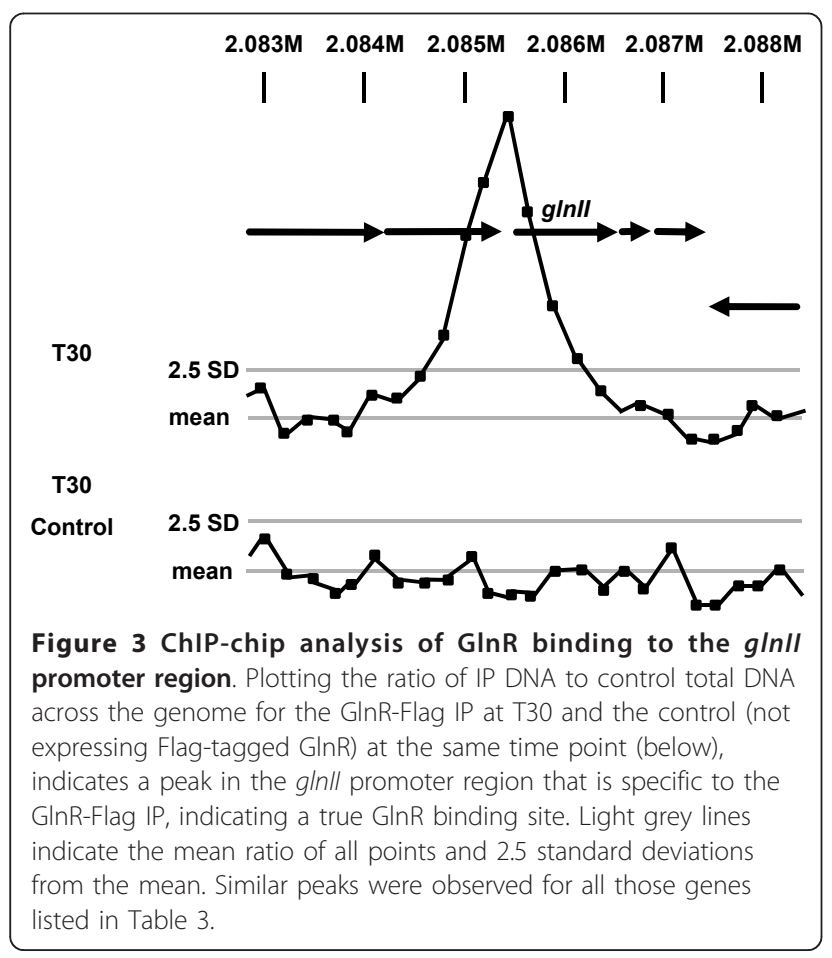

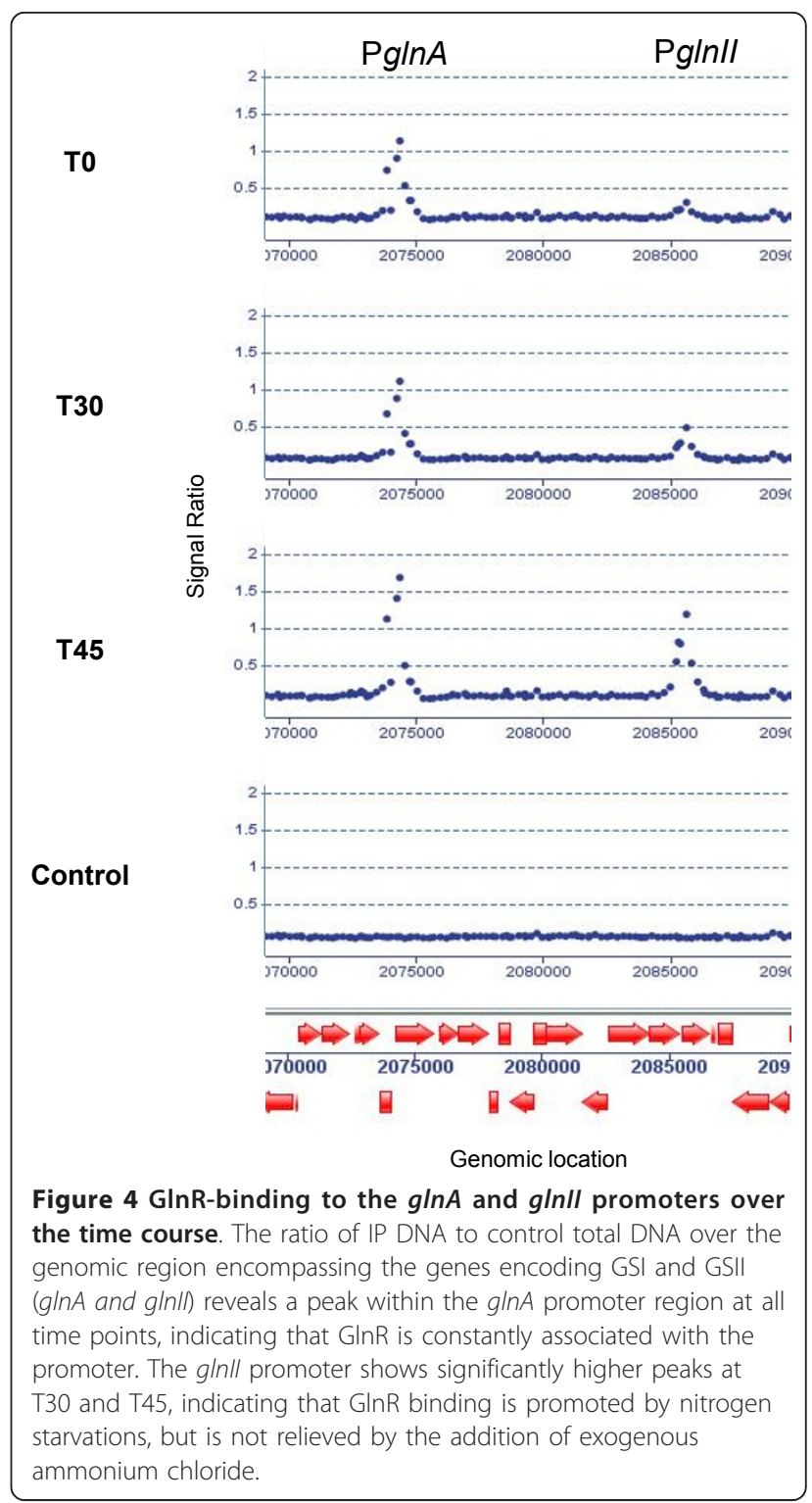

with other target genes, such as $g \ln I I$ or $a m t B$. Such regulation correlates well with a role for GSI as the "housekeeping" glutamine synthetase, which is active during times of nitrogen sufficiency, whilst GSII is induced during conditions of starvation. Expression of GSII-type isoenzymes in low nitrogen levels has also been demonstrated in plant symbiotic Rhizobia species [22].

After 30 minutes of nitrogen starvation $\left(\mathrm{T}_{30}\right)$ many more GlnR peaks were observed. The most highly enriched regions were those containing the $g \ln A$ and $g l n I I$ promoters. The $a m t B$ promoter was also highly represented in the IP material. This coincides with the maximal levels of expression of these genes during the time course. However, by $\mathrm{T}_{45}$ exposure of the starved cultures to exogenously added ammonium chloride did 
not abolish the GlnR binding detected at many promoter sites during $\mathrm{N}$ starvation, despite the fact that by $\mathrm{T}_{45}$ many of these genes, most notably $g \ln I I$ and $a m t B$, showed a marked loss of transcriptional activity. This unexpected phenomenon was observed consistently for nearly all target genes identified, and in duplicate biological experiments. Therefore a simple model, in which nitrogen starvation leads to an increased affinity of GlnR for its target promoters, which is reversed by sufficient levels of nitrogen, does not adequately explain the observed binding activity. To investigate further, an extra ChIP experiment was carried out $30 \mathrm{~min}$ after addition of ammonium chloride $\left(\mathrm{T}_{60}\right)$. However, even at this time point, GlnR was still associated with all target sites identified at $\mathrm{T}_{30}$. It would therefore appear that GlnR assumes different forms during the time course. At $\mathrm{T}_{0}, \mathrm{G} \ln \mathrm{R}$ is present (see Figure $2 \mathrm{~A}$ ) but does not associate with its target promoters, with the exception of $g \ln A$. At $\mathrm{T}_{30}, \mathrm{G} \ln \mathrm{R}$ assumes a form with increased affinity for target sequences and association occurs, along with activation of gene expression. At $\mathrm{T}_{45}$, DNA binding is unaffected, but transcriptional activity from target genes is abolished, indicating that a transcriptionally inactive form of GlnR is associated with target promoters for at least $30 \mathrm{~min}$ after addition of ammonium chloride (Figure 4). As GlnR is a member of the OmpR winged helix-turn-helix family of transcriptional regulators, whose activities are classically modified via phosphorylation [23], it may be that phosphorylation states of $G \ln R$ account for the differently active forms. However, many atypical members of the OmpR family that do not undergo phosphorylation have also been characterised [24]. An alternative explanation is that transcriptional activity may still persist at the T45 and T60 time points but stability of target gene mRNA may be severely reduced, leading to a drop in the measured transcript level.

\section{Promoters enriched in GInR immunoprecipitates}

All of the reproducible GlnR-binding sites (observed in at least two experiments and absent within the control) were located within intergenic regions. A total of thirty six such peaks were identified and Table 3 lists the genes located immediately downstream of the binding sites. Five of these genes; $g \ln A, g \ln I I, a m t B$, ure $A$ and Sven_1860 (SCO2195), are known to be regulated by GlnR in S. coelicolor $[11,12]$. However, none of the promoter regions of the eight other $S$. venezuelae genes that are homologous to GlnR-regulated genes in S. coelicolor was enriched in this study.

\section{The conserved GlnR binding sequence}

The identification of a consensus GlnR binding site has proven to be of great value in identifying GlnR-regulated genes [11]. To identify conserved sequences within the promoter regions found to be GlnR-associated in vivo in S. venezuelae, 250 bp sequences of each promoter region were aligned and a consensus sequence (Figure 5, GTnAC- $\mathrm{n}_{6}-\mathrm{GTnAC}$ ) was derived using MEME [20]. Matches present in each promoter sequence are indicated in Table 3. Of the 36 peaks identified, 27 have strong candidate sites from which the MEME motif was derived; however, nine promoter regions lacked a consensus sequence. One such promoter region is that of Sven_2720 encoding a putative transcriptional regulator. Despite lacking the conserved motif, the gene is highly regulated in response to nitrogen availability (induced 21 -fold in the wild-type strain by $\mathrm{N}$ starvation) in a manner that is exquisitely GlnR-dependent (at $\mathrm{T}_{30}$ the level of transcript present in the wild-type strain is 14fold greater than that in the $g \ln R$ mutant) and GlnR is associated with the promoter region in vivo. EMSA experiments with purified GlnR (data not shown) revealed retardation of DNA sequences upstream of $g \ln A, g \ln I I, a m t B$ and Sven_7046, all of which contain the conserved GlnR binding motif. Mobility of the promoter region of Sven_2720 was unaffected in the presence of $G \ln R$.

\section{Discussion}

In this study we combined transcriptomic and ChIPchip analyses to investigate the genetic control of nitrogen regulation in S. venezuelae. We identified a large number of genes within the GlnR regulon but, like others [9], we could not identify a role for the GlnR homologue GlnRII in nitrogen regulation.

The genes identified here can be divided into four categories: i) those that responded to nitrogen availability in a GlnR-dependent manner and where GlnR was associated with the promoter region; ii) those that responded in a GlnR-dependent manner, but showed no GlnR interaction at the promoter and are potentially modulated through another regulatory protein iii) those that responded to nitrogen status independently of GlnR, and iv) those GlnR targets identified by ChIP-chip that showed no response to nitrogen status under the conditions studied. For categories i) and iv), we identified 36 in vivo binding sites on the S. venezuelae chromosome for the nitrogen responsive transcriptional regulator $G \ln R$, and these cover three major aspects of nitrogen metabolism.

\section{Primary nitrogen metabolism}

As expected, genes that encode proteins known or likely to be directly involved in nitrogen metabolism are highly represented among the GlnR targets. Such functions include the assimilation of nitrogen, either from ammonium (AmtB, GlnK, GlnD, GSI, GSII, glutamate synthase) 
Table 3 Genes directly adjacent to peaks identified in ChIP-chip analysis

\begin{tabular}{|c|c|c|c|c|}
\hline Gene ID & $\begin{array}{l}\text { S. coelicolor } \\
\text { homologue }\end{array}$ & Annotation & $\begin{array}{l}\text { Fold change in Transcript } \\
\text { level at T30 in } g \ln R \text { strain }\end{array}$ & MEME-Identifed GInR concensus sites \\
\hline Sven_1863 & SCO2198 & GSI & -1.2 & 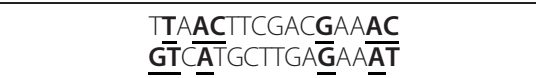 \\
\hline Sven_1874 & SCO2210 & GSII & -291.6 & $\begin{array}{l}\text { GTAACACGGGGTTCAC } \\
\overline{G C} A \overline{A C C} C G A C G G \underline{G} \bar{A} \bar{A} \bar{A} T\end{array}$ \\
\hline Sven_7046 & $\mathrm{n} / \mathrm{a}$ & NRPS cluster & 1.1 & $\underline{\text { GAAACACGGGCGAAAC }}$ \\
\hline Sven_5517 & SCO5842 & Putative acetyltransferase & 1.4 & $\mathrm{n} / \mathrm{a}$ \\
\hline Sven_6731 & SCO5931 & Xylanase & -1.5 & 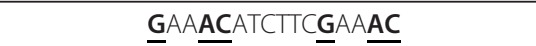 \\
\hline Sven_5279 & SCO5583 & AmtB & -624.7 & 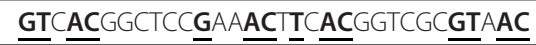 \\
\hline Sven_4770 & $\mathrm{n} / \mathrm{a}$ & Unknown & -1.1 & TIAACGCGCAGGCA $\underline{A C}$ \\
\hline $\begin{array}{l}\text { Sven_3917/ } \\
3918\end{array}$ & $\begin{array}{l}\text { SCO4159/ } \\
4160\end{array}$ & GlnR/putative hydrolase & $(\mathrm{n} / \mathrm{a}) / 30.7$ & 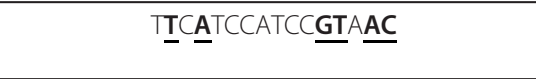 \\
\hline $\begin{array}{l}\text { Sven_6152/ } \\
6153\end{array}$ & $\mathrm{n} / \mathrm{a}$ & ATP-cassette/cytochrome P450 & $1.0 /-1.2$ & 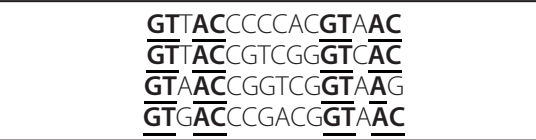 \\
\hline $\begin{array}{l}\text { Sven_6199/ } \\
6200\end{array}$ & $\mathrm{n} / \mathrm{a}$ & NRPS cluster & $1.7 / 3.2$ & 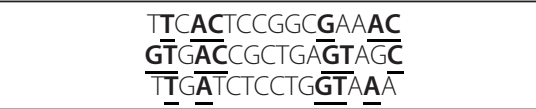 \\
\hline Sven_2720 & SCO2958 & $\begin{array}{l}\text { Fused RR/uroporphrinogen III } \\
\text { synthase }\end{array}$ & -13.7 & $\mathrm{n} / \mathrm{a}$ \\
\hline Sven_2830 & $\mathrm{n} / \mathrm{a}$ & $\beta$-glucan synthesis & -1.4 & $\mathrm{n} / \mathrm{a}$ \\
\hline $\begin{array}{l}\text { Sven_0629/ } \\
0630\end{array}$ & $\begin{array}{l}\text { SCO6598/ } \\
0545\end{array}$ & $\begin{array}{l}\text { Lacl family repressor/secreted } \\
\text { protein }\end{array}$ & $2.5 / 1.5$ & 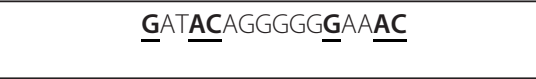 \\
\hline Sven_0867 & SCO1293 & $\mathrm{N}$-acetyl glutamate synthase & -9.1 & TIAACCCGTCAGTCAC \\
\hline Sven_1634 & SCO2008 & $\begin{array}{l}\text { Branched chain amino acid } \\
\text { binding protein }\end{array}$ & -1.3 & AIIAACAAGACAGTC $\underline{\mathbf{A C}}$ \\
\hline Sven_1677 & SCO2026 & Glutamate synthase & -1.1 & $\underline{\underline{G T}} \underline{A A C C T G C A C G A A} \underline{A} T$ \\
\hline Sven_5967 & SCO3051 & FadE acetyl CoA dehydrogenase & -1.3 & 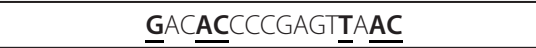 \\
\hline Sven_6632 & SCO5685 & Putative sugar hydrolase & 1.4 & 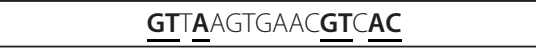 \\
\hline Sven_0035 & & Secreted protein & -1.2 & GTGACGCCGAGGTTAC \\
\hline Sven_2895 & SCO3092 & Fragment of NADH dehydrogenase & 1 & 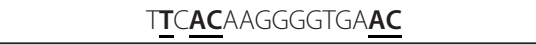 \\
\hline Sven_2285 & SCO4892 & Transcriptional regulator & 1.1 & GAAACACCCTGGTAAC \\
\hline Sven_6163 & $\mathrm{n} / \mathrm{a}$ & Unknown & -1.6 & $\mathrm{n} / \mathrm{a}$ \\
\hline Sven_2694 & SCO2937 & Transcriptional regulator & -1.4 & $\mathrm{n} / \mathrm{a}$ \\
\hline Sven_0835 & SCO1236 & UreA & -2.5 & TIAACGAGCCG $\underline{\mathbf{G} A A} \underline{A} \mathrm{~A}$ \\
\hline $\begin{array}{l}\text { Sven_1338/ } \\
1339\end{array}$ & sCO1721/n/a & $\begin{array}{l}\text { Probable serine/threonine protein } \\
\text { kinase }\end{array}$ & $1.6 /-1.4$ & 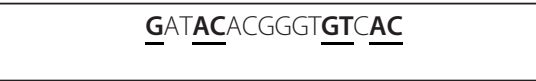 \\
\hline Sven_1860 & SCO2195 & Unknown & -4.5 & 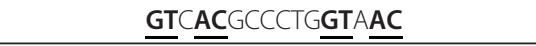 \\
\hline Sven_6307 & SCO6473 & Crotonyl-CoA reductase & -1.7 & $\mathrm{n} / \mathrm{a}$ \\
\hline $\begin{array}{l}\text { Sven_5972/ } \\
5973\end{array}$ & $\mathrm{n} / \mathrm{a}$ & $\begin{array}{l}\text { JadR2/JadR1 (and small orf } \\
\text { inbetween) }\end{array}$ & $1.1 /-1.7$ & 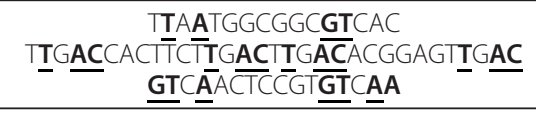 \\
\hline Sven_0812 & SCO2423 & Secreted protein & 1.3 & $\underline{\mathrm{GT}} T \underline{\mathrm{CCCGCAAGTAAC}}$ \\
\hline $\begin{array}{l}\text { Sven_1894/ } \\
1895\end{array}$ & $\begin{array}{l}\text { SCO2231/ } \\
2232\end{array}$ & $\begin{array}{l}\text { Maltose binding protein/ } \\
\text { transcriptional repressor }\end{array}$ & $1.1 / 1.2$ & 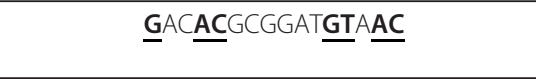 \\
\hline Sven_3785 & SCO4034 & RNA polymerase sigma factor $\mathrm{N}$ & -1 & $\mathrm{n} / \mathrm{a}$ \\
\hline Sven_4759 & $\mathrm{n} / \mathrm{a}$ & $\begin{array}{l}\text { Putative peptide transport system } \\
\text { secreted peptide-binding protein }\end{array}$ & 1.6 & $\mathrm{n} / \mathrm{a}$ \\
\hline Sven_1354 & SCO1735 & Probable secreted lipase & 1.3 & 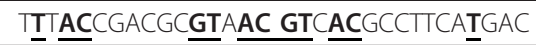 \\
\hline $\begin{array}{l}\text { Sven_6299/ } \\
6300\end{array}$ & n/a/SCO6803 & Epimerase/acetyl transferase & $1.9 /-6.1$ & TICACGTGCCCGAA $\underline{\text { AC }}$ \\
\hline
\end{tabular}


Table 3 Genes directly adjacent to peaks identified in ChIP-chip analysis (Continued)

\begin{tabular}{lll}
\hline Sven_7354 SCO7012 & $\begin{array}{l}\text { Putative binding protein } \\
\text { dependent transport protein } \\
\text { permease }\end{array}$ \\
\hline Sven_7089 n/a & Assimilatory nitrate reductase & $-\mathbf{3 . 7}$ \\
\hline $\begin{array}{l}\text { Peaks were called as present when two or more consecutive probe signals were greater than 2.5 standard deviations above the mean. Duplicate biological } \\
\text { experiments were performed for each time point, with independent hybridisations. Peaks listed were present in at least two independent samples. Sections of } \\
\text { sequences in bold and underlined are those that match the proposed GlnR consensus sequence. }\end{array}$
\end{tabular}

or from alternative $\mathrm{N}$ sources such as urea or nitrate (urease, nitrate reductase). GlnR also regulates production of N-acetyl-glutamate synthase, which, as part of the arginine biosynthesis pathway, synthesises $\mathrm{N}$-acetyl-glutamate from glutamate and acetyl-CoA and whose activity is dependent on cellular nitrogen levels [25]. All of these genes are regulated directly, and possibly solely, by GlnR under the conditions used in these experiments. Two other genes that fall in category i) but have no known function are Sven_1860, encoding a small (71 amino acid) protein, and Sven_2720, encoding a protein with homology to a winged helix-turn-helix motif at the C-terminus and to uroporphyrinogen III synthase at the $\mathrm{N}$-terminus. Based on the regulatory profiles of these genes, they too may be directly involved in primary nitrogen metabolism, and provide interesting targets for future study.

\section{Nitrogen scavenging}

Several genes downstream of GlnR-binding sites (Sven_1634, Sven_4759 and Sven_7354) are predicted to encode periplasmic binding protein (PBP) components of $A B C$ transport systems with substrates such as amino acids and small peptides, suggesting roles in scavenging of alternative nitrogen sources during starvation. Other GlnR-targets encode predicted secreted proteins involved in the degradation of various macromolecules, such as the predicted glycosyl hydrolases, Sven_6731, encoding a xylanase, and Sven_6632, encoding a $\beta$-glucosidase, involved in the degradation of plant

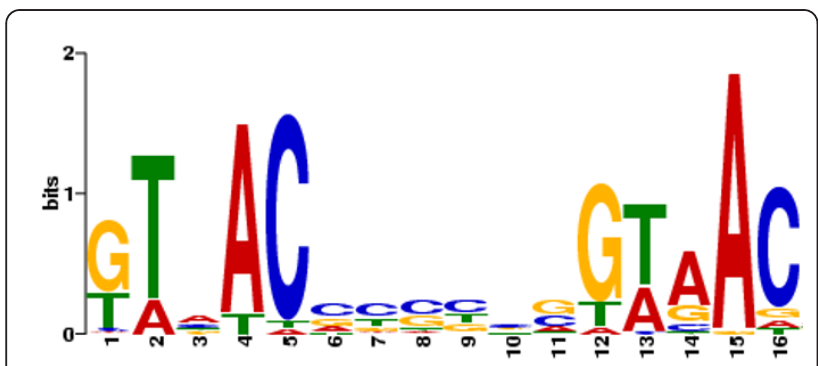

Figure 5 MEME-derived consensus sequence from GInR binding regions identified by ChIP-chip analysis. Consensus

GInR-binding motif generated from 250 bp regions surrounding the peaks identified in ChIP-chip experiments. The genes used to generate the consensus sequence are listed in Table 3. cell wall polysaccharides [26,27], a predicted peptidase (Sven_6152), and a predicted lipase (Sven_1354). Production of an array of degradative enzymes upon nitrogen starvation may be an attempt to release nitrogen and/or other nutrients, either from plant material or other organisms co-habiting the soil environment in which Streptomyces species have evolved.

Many of the genes encoding secreted proteins and PBPs fall into category iv), i.e. GlnR targets in ChIPchip experiments that were not identified as nitrogen responsive in the transcriptional studies. However, the absence of a nitrogen-dependent transcriptional response may reflect the starvation conditions used in this study. The proteins encoded by these genes are not involved directly in nitrogen metabolism, but may, in some circumstances, perform useful roles under nitrogen-limited conditions. Therefore, for optimal induction, these systems may require additional input signals in addition to nitrogen limitation, such as substrate-dependent induction, that were absent in our experimental conditions.

\section{Secondary Metabolism}

GlnR binds to the intergenic region between the divergently transcribed $j a d R 1$ and $j a d R 2$ genes, which encode transcriptional regulators that activate and repress, respectively, expression of the jadomycin biosynthetic genes [28]. Microarray data suggest that transcription of jadR1 is activated by GlnR. Expression of jadR1 is induced 3.3-fold in response to nitrogen starvation in the wild-type strain and this level is repressed 1.2 fold upon ammonium addition. Consistent with this, levels of jadR1 transcription in the $g \ln R$ mutant during nitrogen starvation are 1.7-fold lower than in the wild-type strain (Table 3). Given the antimicrobial activity of jadomycin B [29], GlnR regulation may facilitate induction of expression as a response to nitrogen limitation caused by the presence of competing microorganisms. None of the other genes comprising the jadomycin B gene cluster show any significant changes in expression in response to nitrogen limitation, neither in the wildtype nor the $g \ln R$ mutant, indicating that increased expression of JadR1 alone is not sufficient to activate expression of the cluster. Lack of induction may be due to the action of the repressor JadR2, which is only 
deactivated upon stress treatments such as heat or ethanol shock [30].

GlnR binding sites were also identified upstream of Sven_7046 and within the intergenic region of Sven_6199 and Sven_6200. These uncharacterised genes are located within regions that have been annotated as potentially encoding non-ribosomal peptide synthetase (NRPS)-like gene clusters. All three were down-regulated in response to nitrogen limitation, but their expression, and that of adjacent genes, was not significantly altered in the $g \ln R$ deletion strain.

\section{Comparisons with the $S$. coelicolor GInR regulon}

Many of the genes responsive to changes in nitrogen availability in $S$. venezuelae are also regulated by GlnR in S. coelicolor. Of the 15 genes identified as GlnR targets in S. coelicolor [11], 13 have strong homologues in S. venezuelae (genes are considered to be homologous if they are reciprocal top BLAST hits). Four of these 13 genes, namely the $a m t B-g \ln K-g \ln D$ operon and $g \ln I I$, were among the twenty genes showing the largest induction upon N-starvation (Table 1). A further two targets, ure $A$ encoding the $\gamma$-subunit of urease and Sven_1860 (SCO2195) encoding a small protein of unknown function, also responded significantly (Additional file 2). The remaining seven $S$. venezuelae genes whose homologues are GlnR-regulated in $S$. coelicolor did not pass the filtering criteria, although one, $g \ln A$, only narrowly failed, being induced 1.9-fold upon N-starvation and repressed 1.7-fold by exogenous ammonium. As observed in S. coelicolor [11], induction of $g \ln A$ was notably lower than that of $\operatorname{gln} I I$ (6.5-fold).

The lack of a marked response to N-starvation by some candidate genes could reflect species differences in the GlnR regulon, or differences in experimental conditions. In this study with $S$. venezuelae, N-starvation was achieved by complete removal of any $\mathrm{N}$-source, whereas in $\mathrm{S}$. coelicolor $\mathrm{N}$-starvation was achieved by a switch from growth on ammonium to growth on nitrate. S. venezuelae nirB, encoding a nitrite reductase subunit, did not respond to $\mathrm{N}$-starvation but the gene was induced in a GlnR-dependent manner in S. coelicolor. Hence the presence of nitrate/nitrite may be required for nirB induction. Similarly, whereas the complete absence of nitrogen induced ureA in $S$. venezuelae, $S$. coelicolor ure $A$ was repressed upon N-starvation, perhaps indicating a preference for nitrate over urea as a nitrogen source in the latter species. We have not investigated the in vivo promoter binding activity of S. coelicolor GlnR and there is no published data on this. So it is currently unknown whether $S$. coelicolor GlnR also binds to target promoters in vivo under conditions in which transcriptional activation does not occur.

\section{The GlnR binding site consensus sequence}

The MEME algorithm identified a common motif present in twenty-seven of the thirty-six GlnR target regions identified by ChIP-chip, in some cases in multiple copies (Table 3). The motif identified was similar to that proposed for $S$. coelicolor but with some significant differences. The binding site (GlnR box) proposed by Tiffert et al. contained an "a-site" (gTnAc) located 6 bps upstream of a "b-site" (GaAAc), giving a consensus sequence of gTnAc- $n_{6}$-GaAAc [11]. Interestingly, recent work by Wang and Zhao [12] identified a novel binding site configuration in the promoter region of S. coelicolor nasA (encoding nitrate reductase). GlnR recognition of the nas $A$ promoter is mediated by two GTAAC "a-sites" separated by $18 \mathrm{bps}$, leading the authors to suggest that a "b-site"might not be obligatory. The motif we identified in $S$. venezuelae, GTnAC- $n_{6}-$ GTnAC (Figure 5), is essentially two copies of the "a-site" separated by 6 bps. Hence the distinction between the "a" and "b" sites is less well defined in $S$. venezuelae where, although there are several examples of GAnAC occupying the "b-site", GTnAC is much more common (Table 3).

Tiffert et al. [11] suggested that GlnR binding may follow the OmpR model, such that the more highly conserved "b" site has a higher affinity for GlnR, whilst the less well conserved "a-site" has a lower affinity. However the sequence derived in their study was based initially on alignments of the strongly GlnR-regulated promoters of $a m t B$ and $g \ln A$ (as well as SCO1863, which has no homologue in $S$. venezuelae), and may be biased towards a higher affinity "b-site". The promoters of $a m t B$ and $g \ln A$ in $S$. venezuelae both contain a "b-site" with the sequence GAAAC, and both have two tandem copies of the minimal binding sequence (i.e., GTnAC- $\mathrm{n}_{6}-\mathrm{GTnAC}$ $\left.\mathrm{n}_{6}-\mathrm{GTnAC}-\mathrm{n}_{6}-\mathrm{GTn} A C\right)$, an arrangement suggested to be the predominant GlnR-binding site in S. coelicolor [11]. This tandem arrangement with a preponderance of GAAAC in the "b" position may be indicative of strong GlnR regulation. However, it is not representative of the majority of GlnR binding sites observed in vivo in S. venezuelae, where a single occurrence of GTnAC- $\mathrm{n}_{6}$ $\mathrm{GTnAC}$ is the most common motif.

\section{Promoters lacking an identifiable GlnR box}

Nine of the thirty-six regions identified in ChIP-chip experiments do not contain a GlnR binding motif. Transcription factors binding to non-consensus sequences are a common observation in ChIP-chip studies (reviewed in detail by Wade et al. [31]). Examples include well-studied transcription factors such as Fnr of Escherichia coli [32] and CtrA of Caulobacter crescentus [33]. Likewise, studies of Bacillus subtilis SpoA [34] 
revealed many in vivo binding sites that were not bound in an in vitro assay. Local changes in DNA topology, or the co-operative interactions of multiple transcriptional factors in vivo, may reduce the requirement for the consensus sequence [31] and facilitate binding to nonconsensus sites.

As discussed for nas $A$ of $S$. coelicolor, GlnR is capable of binding to two distantly separated copies of the GTnAC motif. Inspection of promoter regions that do not contain the full consensus sequence reveals several that possess multiple copies of the GTnAC motif. For example, the Sven_2720 promoter region contains three separate copies of GTnAC separated by regions of thirty nine and thirty three base pairs. Further work is required to establish their possible role in facilitating GlnR binding.

\section{Conclusions}

GlnR is the global nitrogen regulator in actinomycetes and plays a key role in regulating the assimilation and utilisation of nitrogen. This study has extended our knowledge of the GlnR regulon in streptomycetes. It has also indicated a possible link between GlnR and transcription of JadR1, the pathway specific regulator of the jadomycin B cluster, as well as secreted degradative enzymes and several proteins with functions relating to transport. Application of ChIP-chip has provided fresh insight into the DNA sequences to which GlnR binds in vivo and has shown that GlnR is able to associate with target promoters in both transcriptionally active and inactive forms.

\section{Methods}

\section{Strains, primers and plasmids}

S. venezuelae ATCC 10712 was the wild-type strain used throughout this study. All mutants were generated using PCR targeting( Gust et al. [19]). The entire coding region of each gene, including start and stop codons, was replaced with an apramycin resistance cassette amplified from pIJ773 [19]. For generation of the $g \ln R:: a p r^{R}$ mutant, the forward primer was 5'-CACCTTGGCCACGCG CGGCAGTCTACGCGGGGTGACCTAATTCCG

GGGATCCGTCGACC-3' and the reverse primer was 5-CGACCGACCGACGGCGGGTCCGGCAGGTGGT GCGCGATGTGTAGGCTGGAGCTGCTTC-3.

For the $g \ln R I I:: a p r^{R}$ mutant, the forward primer was 5'-TCCGTTCGTTTCTTCGCGCGAAAGAGCTGAGACCTCATGATTCCGGGGATCCGTCGACC-3', and the reverse was 5'-TGGTGTCCAGGACGAGGGCGAAGGCGAACTGACGGATCATGTAGGCTGGAG CTGCTTC-3'.

Primers used for qRT-PCR to measure $a m t B$ levels were 5-TCCGCCGCCAACACCGGGTTCA-3 and 5-GGCGAGTGCCGGGGTCATCAGC-3, and for $h r d B$ levels 5-CATGGCGGACCAGGCCCGAACC-3 and 5-CCTGGAGCATCTGGCGCTGCAC-3.

FLAG-tagging of GlnR was achieved by amplifying a region from genomic DNA that contained the entire GlnR coding sequence excluding the stop codon, along with 264 bp of upstream sequence containing the $g \ln R$ promoter, using the primer pair 5-TATTATAAGCT TGTGGGCTATTCTCCT-3 and 5-CCTACCGGCAG GTCGCACTGTGGC-3. The amplicon was blunt-ended using Pfu polymerase (Invitrogen) and cloned into the StuI site of pIJ10500 (courtesy of C den Hengst, John Innes Centre, Norwich), a modified version of the integrative pMS82 vector [21] containing a Streptomyces codon usage-optimised triple FLAG epitope cassette, thereby creating a $\mathrm{C}$-terminally tagged $\mathrm{Gln} \mathrm{R}$ protein expressed from its native promoter in construct pIJ12248.

\section{Growth conditions}

For all liquid culture experiments S. venezuelae was grown in $30 \mathrm{ml}$ batches of Evans defined minimal media [18]. The nitrogen source used was $30 \mathrm{mM} \mathrm{NH}_{4} \mathrm{Cl}$, unless stated otherwise. To transfer S. venezuelae between media types, the culture was transferred to a falcon tube and very briefly centrifuged to form a pellet. Media was decanted and the pellet resuspended in the alternative media. For growth on solid media, Evans was supplemented with agarose at a final concentration of $2 \% \mathrm{w} / \mathrm{v}$.

\section{RNA extraction}

At each experimental time point $10 \mathrm{ml}$ of culture were centrifuged briefly to pellet the mycelium which was rapidly frozen under liquid nitrogen. Frozen pellets were ground using a pestle and mortar containing liquid nitrogen. The broken cells were mixed with $1.5 \mathrm{ml}$ of TRI $^{\circledR}$ Reagent (Sigma) and left at room temperature for $5 \mathrm{~min}$ before addition of $300 \mu \mathrm{l}$ chloroform. The mixture was vortexed briefly then incubated at room temperature for $2 \mathrm{~min}$. Samples were centrifuged for 10 min at $13000 \mathrm{rpm}$ in a bench top microfuge. The aqueous phase, containing RNA, was harvested and RNA was purified using an RNeasy ${ }^{\circledR}$ Mini Kit (Qiagen) as per manufacturer's instructions, including the recommended on-column DNase digestion. The final elution step was carried out with $50 \mu \mathrm{l}$ of nuclease-free water (Qiagen).

\section{qRT-PCR analysis}

Specific primers for $a m t B$ and $h r d B$ were designed using the Primer3 web-based tool [35]. RNA (5 $\mu \mathrm{g})$ was treated with amplification grade RNase-free DNaseI (Invitrogen) according to the manufacturer's instructions. The resulting RNA was used as template for cDNA synthesis in a $20 \mu \mathrm{l}$ reaction using Superscript III First 
Strand Synthesis Supermix (Invitrogen) according to manufacturer's instructions. PCR was performed at $25^{\circ} \mathrm{C}$ for $10 \mathrm{~min}, 42^{\circ} \mathrm{C}$ for $120 \mathrm{~min}, 50^{\circ} \mathrm{C}$ for $30 \mathrm{~min}, 55^{\circ} \mathrm{C}$ for $30 \mathrm{~min}$ and $85^{\circ} \mathrm{C}$ for $5 \mathrm{~min}$. Samples were diluted $\mathrm{x} 100$ in Tris-EDTA ( $10 \mathrm{mM}, \mathrm{pH} 8.0)$, and $2.5 \mu \mathrm{l}$ were used for quantitative SYBR Greener qPCR supermix (Invitrogen) reactions according to manufacturer's instructions. $200 \mathrm{nM}$ of forward and reverse primers were used in each $25 \mu$ l reaction. PCR was performed in a BioRad Chromo4 machine at $50^{\circ} \mathrm{C}$ for $2 \mathrm{~min}, 95^{\circ} \mathrm{C}$ for $10 \mathrm{~min}$, followed by 40 cycles of $95^{\circ} \mathrm{C}$ for $15 \mathrm{~s}$ and $58^{\circ} \mathrm{C}$ for $60 \mathrm{~s}$. Identical reactions were performed using sequential dilutions of genomic DNA to generate a standard curve for each primer pair. Biological experiments were performed in triplicate, the results were analysed using Opticon 2 Monitor software (MJ Research) and values were normalized to levels of $h r d B$ expression.

\section{Affymetrix GeneChip hybridization and data collection for expression studies}

Purified total RNA $(10 \mu \mathrm{g})$ was used as the template for production of cDNA that was subsequently labelled and fragmented for hybridisation to Affymetrix Streptomyces diS_div712a GeneChip arrays as described previously by Hesketh et al [36]. Hybridizations were performed according to protocols provided by the manufacturer in a Hybridization Oven model 640 (Affymetrix.). The GeneChips were washed and stained with streptavidinphycoerythrin using GeneChip fluidics workstation model 450, and then scanned with a GeneArray Scanner Model 3000 7G.

\section{Data analysis}

Expression data were imported into GeneSpring 9.0 (Agilent Technologies), normalised using the Robust Multichip Average algorithm (RMA), converted to $\log _{2}$ values and normalised per gene to the median.

Microarray data have been deposited in the ArrayExpress datatbase, under the accession number E-MEXP2684.

Two-way ANOVA was performed in GeneSpring using the parametric test option with a false discovery rate of $P<0.01$ or $P<0.05$, and assuming variances to be equal. $P$ values were corrected using the Benjamini and Hochberg false discovery rate multiple testing correction procedure.

\section{Western blotting}

S. venezuelae strains were grown to an $\mathrm{OD}_{600}$ of $\sim 0.6$; $10 \mathrm{ml}$ of culture was briefly centrifuged to form a pellet, which was resuspended in $1.5 \mathrm{ml}$ of SP buffer and sonicated on ice. Multiple $15 \mathrm{~s}$ bursts of sonication at $10 \mathrm{kHz}$ were performed with $60 \mathrm{~s}$ intervals between bursts, until the suspension became clear. Cell debris was removed by centrifugation. Protein concentrations of cell fractions were determined using the Bio-Rad protein assay system using bovine serum albumin as a standard. In all cases, $5 \mu \mathrm{g}$ of total protein was separated by SDS-PAGE (15\% polyacrylamide). After transfer to a nitrocellulose membrane (Hybond ECL nitrocellulose membrane; Amersham), the proteins were reacted with monoclonal ANTI-FLAG ${ }^{\circledR}$ M2 antibody (Sigma).

\section{Chromatin-immunoprecipitation \\ Cell preparation and cross-linking}

Fifty millilitre cultures of $S$. venezuelae were grown to an $\mathrm{OD}_{600}$ of $\sim 0.6$ and formaldehyde (Sigma) was added to a final concentration of $1 \%$. Cross linking was allowed to proceed for $30 \mathrm{~min}$ of continued incubation at $30^{\circ} \mathrm{C}$. The addition of glycine, at a final concentration of $125 \mathrm{mM}$, halted the cross-linking. Cells were briefly centrifuged to form a pellet and washed twice with ice-cold PBS. The pellet was resuspended in $750 \mu \mathrm{l}$ of lysis buffer $(10 \mathrm{mM}$ Tris- $\mathrm{HCl} \mathrm{pH}$ 8.0, $50 \mathrm{mM} \mathrm{NaCl}, 10 \mathrm{mg} / \mathrm{ml}$ lysozyme, supplemented with 1 pellet of Roche complete mini EDTAfree protease inhibitor per $10 \mathrm{ml}$ of buffer) and incubated for $25 \mathrm{~min}$ at $25^{\circ} \mathrm{C}$. Samples were placed on ice for $2 \mathrm{~min}$ after addition of $750 \mu \mathrm{l}$ of IP buffer $(100 \mathrm{mM}$ Tris- $\mathrm{HCl}$ pH 8.0, $250 \mathrm{mM} \mathrm{NaCl}, 0.5 \%$ Triton X-100, 0.1\% SDS, also supplemented with protease inhibitor). Samples at this point resembled a slurry that was sonicated repeatedly at $10 \mathrm{kHz}$ in $15 \mathrm{~s}$ bursts; sub-fractions were taken at frequent intervals, extracted twice with phenol/chloroform and run on agarose gels to check fragment size. Sonication was complete, typically after 7-8 cycles, when fragments were between 300 and $1000 \mathrm{bp}$ in length, centred on 500 bp. Debris was removed from the sonicated extracts by centrifugation at maximum speed in a bench top microfuge for $10 \mathrm{~min}$ at $4^{\circ} \mathrm{C}$ and supernatant fluid was retained. At this point $25 \mu \mathrm{l}$ of the extract was stored to be used as the control "total DNA" whilst the remainder, $\sim 725 \mu \mathrm{l}$, was used in immunoprecipitation.

\section{Immunoprecipitation, reversal of cross-linking, and elution of DNA}

Initial pre-clearance of the extracts was performed by incubation for $1 \mathrm{~h}$ at $4^{\circ} \mathrm{C}$ on a rotating wheel after addition of $1 / 10$ volume of a $50 \%$ Protein A-sepharose slurry (Sigma) equilibrated in IP buffer. The mixture was centrifuged to pellet the beads, the cleared extract harvested and mixed with $5 \mu \mathrm{l}$ monoclonal ANTIFLAG $^{\circledR}$ M2 antibody (Sigma). Incubation was then continued overnight. A $1 / 10$ volume of a fresh $50 \%$ Protein A-sepharose slurry was added and samples incubated for a further $4 \mathrm{~h}$ at $4^{\circ} \mathrm{C}$ before centrifugation for $5 \mathrm{~min}$ at $3500 \mathrm{rpm}$ in a microfuge to harvest the bead-antibody-chromatin complex. This was washed once in $0.5 x$ IP buffer and twice in IP buffer each for 
15 min with gentle agitation. Elution of DNA was performed by addition of $150 \mu \mathrm{l}$ of IP elution buffer (50 mM Tris- $\mathrm{HCl} \mathrm{pH} 7.6,10 \mathrm{mM}$ EDTA, 1\% SDS) to the beads, as well as to $10 \mu \mathrm{l}$ of the "total DNA" control, and incubation at $65^{\circ} \mathrm{C}$ overnight. Beads were pelleted by centrifugation and the supernatant harvested, treated with $2 \mu \mathrm{l}$ of $10 \mathrm{mg} / \mathrm{ml}$ Proteinase K (Roche) and twice extracted with phenol chloroform. Finally, DNA was purified using the Qiagen QiaQuick according to manufacturer's instructions.

\section{Microarray design, labelling, and hybridization}

Custom made microarray slides, consisting of 44,000 60 -mer oligonucleotide probes covering the entire S. venezuelae genome, were designed and produced by Oxford Gene Technologies (Oxford, UK). Labelling of control total DNA and immunoprecipitated DNA, with $\mathrm{Cy} 5$ and $\mathrm{Cy} 3$ respectively, as well as hybridisation, washing and scanning were performed by Oxford Gene Technologies according to their standard protocols (http://www.ogt.co.uk) previously described in detail for E. coli [37].

\section{Data analysis}

Cy3/Cy5 ratios were calculated for each probe. Ratios were then plotted against genome position. A peak in the plot representing a protein binding site was scored as present when firstly, two consecutive probes gave a ratio that was 2.5 standard deviations above the mean calculated across all probes in at least two of the six experiments, and secondly when this peak was absent in the control sample, derived by immuno-precipitation of a culture of S. venezuelae carrying an empty vector instead of the FLAG-tagged GlnR construct. The ChIP-chip data have been deposited in the ArrayExpress database, under the accession number E-MEXP-2933.

\section{Additional material}

Additional file 1: Microarray expression profiles of $a m t B-g \ln K-g \ln D$, $g \ln A$ and $g / n \mid l$ over the wild-type, $g \ln R$ and $g \ln R I I$ mutant time courses. Expression is the average of three biological replicates and normalised intensity is plotted on a $\log _{2}$ scale. Diagram adapted from GeneSpring 9.0 (Agilent).

Additional file 2: Full list of genes induced $>2$ upon nitrogen starvation, that are also repressed by ammonium.

Additional file 3: Genes induced $>2$ fold by nitrogen starvation and repressed by ammonium in the wild-type strain, but nonresponsive in the $g \ln R$ mutant strain.

List of abbreviations

ChIP: chromatin immuno-precipitation; qRT-PCR: quantitative reversetranscriptase polymerase chain reaction; IP: immunoprecipitation; PBP: periplasmic binding protein; NRPS: non-ribosomal peptide synthetase.

\section{Acknowledgements}

We would like to thank Chris den Hengst for constructs, protocols and advice on ChIP experiments, Maureen Bibb and Andy Hesketh for advice on microarray experiments and Jeremy Thornton for technical assistance. We would like to particularly thank Diversa Corporation (now Verenium

Corporation) for access to the draft S. venezuelae genome sequence and to the Affymetrix microarrays. This work was funded by a grant from the UK Biotechnology and Biological Sciences Research Council.

\section{Author details}

${ }^{1}$ Department of Molecular Microbiology, John Innes Centre, Norwich Research Park, Norwich, Norfolk NR4 7UH, UK. ${ }^{2}$ Institute of Genetics, School of Biology, University of Nottingham, University Park, Nottingham NG7 2RD, UK.

\section{Authors' contributions}

STP carried out all experimental work, participated in design of the study, analysed data and drafted the manuscript. GC programmed analytical tools for interpretation of ChIP-chip and aided the analysis of sequence data. MB participated in design and coordination of the study and helped to draft the manuscript. MM conceived of the study, and participated in its design and coordination and helped to draft the manuscript. All authors read and approved the final manuscript.

Received: 29 November 2010 Accepted: 4 April 2011

Published: 4 April 2011

\section{References}

1. Reitzer L: Nitrogen assimilation and global regulation in Escherichia coli. Annu Rev Microbiol 2003, 57:155-176, Epub 2003 May 2001

2. Burkovski A: Nitrogen control in Corynebacterium glutamicum: proteins, mechanisms, signals. J Microbiol Biotechnol 2007, 17(2):187-194.

3. Sonenshein A: Control of key metabolic intersections in Bacillus subtilis. Nat Rev Microbiol 2007, 5(12):917-927.

4. Wray $L$, Fisher $S$ : The Streptomyces coelicolor $g \ln R$ gene encodes a protein similar to other bacterial response regulators. Gene 1993, 130(1):145-150.

5. Yu H, Peng W, Liu Y, Wu T, Yao Y, Cui M, Jiang W, Zhao G: Identification and characterization of $g \ln A$ promoter and its corresponding transregulatory protein $\mathrm{GlnR}$ in the rifamycin SV producing actinomycete, Amycolatopsis mediterranei U32. Acta Biochim Biophys Sin (Shanghai) 2006, 38(12):831-843.

6. Amon J, Bräu T, Grimrath A, Hänssler E, Hasselt K, Höller M, Jessberger N, Ott L, Szököl J, Titgemeyer F, et al: Nitrogen control in Mycobacterium smegmatis: nitrogen-dependent expression of ammonium transport and assimilation proteins depends on the OmpR-type regulator GlnR. J Bacteriol 2008, 190(21):7108-7116.

7. Malm S, Tiffert Y, Micklinghoff J, Schultze S, Joost I, Weber I, Horst S, Ackermann B, Schmidt M, Wohlleben W, et al: The roles of the nitrate reductase NarGHJl, the nitrite reductase NirBD and the response regulator GlnR in nitrate assimilation of Mycobacterium tuberculosis. Microbiology 2009, 155(Pt 4):1332-1339.

8. Wray $L J$, Atkinson M, Fisher S: Identification and cloning of the glnR locus, which is required for transcription of the $g \ln A$ gene in Streptomyces coelicolor A3(2). J Bacteriol 1991, 173(22):7351-7360.

9. Fink D, Weissschuh N, Reuther J, Wohlleben W, Engels A: Two transcriptional regulators $G \ln R$ and $G \ln R I l$ are involved in regulation of nitrogen metabolism in Streptomyces coelicolor A3(2). Mol Microbiol 2002, 46(2):331-347.

10. Hesketh A, Fink D, Gust B, Rexer H, Scheel B, Chater K, Wohlleben W, Engels A: The GInD and GInK homologues of Streptomyces coelicolor A3 (2) are functionally dissimilar to their nitrogen regulatory system counterparts from enteric bacteria. Mol Microbiol 2002, 46(2):319-330.

11. Tiffert $Y$, Supra $P$, Wurm $R$, Wohlleben W, Wagner R, Reuther J: The Streptomyces coelicolor GInR regulon: identification of new GlnR targets and evidence for a central role of $G \ln R$ in nitrogen metabolism in actinomycetes. Mol Microbiol 2008, 67(4):861-880.

12. Wang J, Zhao G: GInR positively regulates nasA transcription in Streptomyces coelicolor. Biochem Biophys Res Commun 2009, 386(1):77-81.

13. Rodríguez-García A, Sola-Landa A, Apel K, Santos-Beneit F, Martín J: Phosphate control over nitrogen metabolism in Streptomyces coelicolor: 
direct and indirect negative control of $g \ln R, g \ln A, g \ln l \mid$ and $a m t B$ expression by the response regulator PhoP. Nucleic Acids Res 2009, 37(10):3230-3242.

14. Tiffert $Y$, Franz-Wachtel $M$, Fladerer $C$, Nordheim A, Reuther J, Wohlleben W, Mast Y: Proteomic analysis of the GlnR-mediated response to nitrogen limitation in Streptomyces coelicolor M145. Appl Microbiol Biotechnol 2011.

15. Yu H, Yao Y, Liu Y, Jiao R, Jiang W, Zhao G: A complex role of Amycolatopsis mediterranei $\mathrm{GlnR}$ in nitrogen metabolism and related antibiotics production. Arch Microbiol 2007, 188(1):89-96.

16. Bhatnagar $R$, Doull J, Vining L: Role of the carbon source in regulating chloramphenicol production by Streptomyces venezuelae: studies in batch and continuous cultures. Can J Microbio/ 1988, 34(11):1217-1223.

17. Glazebrook M, Doull J, Stuttard C, Vining L: Sporulation of Streptomyces venezuelae in submerged cultures. J Gen Microbiol 1990, 136(3):581-588.

18. Evans CGT, Herbert D, Tempest DW, Ribbons JR, Na DW: Chapter XIII The Continuous Cultivation of Micro-organisms: 2. Construction of a Chemostat. In Methods in Microbiology. Volume 2. Academic Press; 1970:277-327.

19. Gust B, Chandra G, Jakimowicz D, Yuqing T, Bruton C, Chater K: Lambda red-mediated genetic manipulation of antibiotic-producing Streptomyces. Adv Appl Microbiol 2004, 54:107-128.

20. Bailey T, Elkan C: Fitting a mixture model by expectation maximization to discover motifs in biopolymers. Proc Int Conf Intell Syst Mol Biol 1994, 2:28-36.

21. Gregory M, Till R, Smith M: Integration site for Streptomyces phage phiBT1 and development of site-specific integrating vectors. J Bacteriol 2003, 185(17):5320-5323.

22. de Bruijn F, Rossbach S, Schneider M, Ratet P, Messmer S, Szeto W, Ausubel F, Schell J: Rhizobium meliloti 1021 has three differentially regulated loci involved in glutamine biosynthesis, none of which is essential for symbiotic nitrogen fixation. J Bacteriol 1989, 171(3):1673-1682.

23. Egger $L A$, Park $H$, Inouye M: Signal transduction via the histidyl-aspartyl phosphorelay. Genes Cells 1997, 2(3):167-184.

24. Hong E, Lee HM, Ko H, Kim DU, Jeon BY, Jung J, Shin J, Lee SA, Kim Y, Jeon $\mathrm{YH}$, et al: Structure of an atypical orphan response regulator protein supports a new phosphorylation-independent regulatory mechanism. J Biol Chem 2007, 282(28):20667-20675.

25. Xu Y, Labedan B, Glansdorff N: Surprising arginine biosynthesis: a reappraisal of the enzymology and evolution of the pathway in microorganisms. Microbiol Mol Biol Rev 2007, 71(1):36-47.

26. Collins T, Gerday C, Feller G: Xylanases, xylanase families and extremophilic xylanases. FEMS Microbiol Rev 2005, 29(1):3-23.

27. Doi RH, Kosugi A: Cellulosomes: plant-cell-wall-degrading enzyme complexes. Nat Rev Microbiol 2004, 2(7):541-551.

28. Yang $\mathrm{K}$, Han $\mathrm{L}$, He J, Wang $\mathrm{L}$, Vining $\mathrm{L}$ : A repressor-response regulator gene pair controlling jadomycin B production in Streptomyces venezuelae ISP5230. Gene 2001, 279(2):165-173.

29. Jakeman D, Bandi S, Graham C, Reid T, Wentzell J, Douglas S: Antimicrobial activities of jadomycin $B$ and structurally related analogues. Antimicrob Agents Chemother 2009, 53(3):1245-1247.

30. Yang K, Han L, Vining L: Regulation of jadomycin B production in Streptomyces venezuelae ISP5230: involvement of a repressor gene, jadR2. J Bacteriol 1995, 177(21):6111-6117.

31. Wade J, Struhl K, Busby S, Grainger D: Genomic analysis of protein-DNA interactions in bacteria: insights into transcription and chromosome organization. Mol Microbiol 2007, 65(1):21-26.

32. Grainger D, Aiba H, Hurd D, Browning D, Busby S: Transcription factor distribution in Escherichia coli: studies with FNR protein. Nucleic Acids Res 2007, 35(1):269-278

33. Laub M, Chen S, Shapiro L, McAdams H: Genes directly controlled by CtrA, a master regulator of the Caulobacter cell cycle. Proc Natl Acad SC USA 2002, 99(7):4632-4637.

34. Molle V, Fujita M, Jensen S, Eichenberger P, González-Pastor J, Liu J, Losick R: The Spo0A regulon of Bacillus subtilis. Mol Microbiol 2003, 50(5):1683-1701.

35. Rozen S, Skaletsky H: Primer3 on the www for general users and for biologist programmers. Methods Mol Biol 2000, 132:365-386.
36. Hesketh A, Chen W, Ryding J, Chang S, Bibb M: The global role of ppGpp synthesis in morphological differentiation and antibiotic production in Streptomyces coelicolor A3(2). Genome Biol 2007, 8(8):R161.

37. Grainger D, Hurd D, Harrison M, Holdstock J, Busby S: Studies of the distribution of Escherichia coli cAMP-receptor protein and RNA polymerase along the E. coli chromosome. Proc Natl Acad Sci USA 2005, 102(49):17693-17698.

doi:10.1186/1471-2164-12-175

Cite this article as: Pullan et al:: Genome-wide analysis of the role of GlnR in Streptomyces venezuelae provides new insights into global nitrogen regulation in actinomycetes. BMC Genomics 2011 12:175.

\section{Submit your next manuscript to BioMed Central and take full advantage of:}

- Convenient online submission

- Thorough peer review

- No space constraints or color figure charges

- Immediate publication on acceptance

- Inclusion in PubMed, CAS, Scopus and Google Scholar

- Research which is freely available for redistribution 